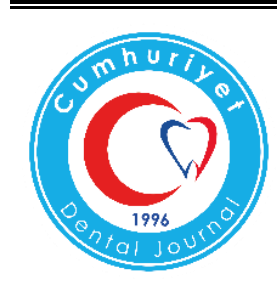

\title{
COMPARISON OF CYCLIC FATIGUE RESISTANCE OF ONE CURVE, HYFLEX EDM, WAVEONE GOLD AND RECIPROC BLUE NICKEL- TITANIUM ROTARY FILES AT INTRA-CANAL TEMPERATURE
}

\begin{abstract}
Objectives: To compare the cyclic fatigue resistances of One Curve (OC), Hyflex EDM (HEDM), WaveOne Gold (WOG), Reciproc Blue (RPC Blue), and nickeltitanium rotary files at intra-canal temperature $\left(35^{\circ} \mathrm{C}\right)$.

Materials and Methods: Twenty OC (25/.06), 20 HEDM (25/.08), 20 WOG (25/.07) and 20 RPC Blue (25/.08) files were tested for cyclic fatigue at intracanal temperature $\left(35^{\circ} \mathrm{C}\right)$. All the instruments were rotated in artificial which were made of stainless steel with an $60^{\circ}$ angle of curvature and a radii of curvatures of $5 \mathrm{~mm}$ until fracture occurred, and the time to fracture was recorded in seconds using a digital chronometer and the number of cycles to fracture (NCF) for each file was calculated. The Kruskal-Wallis test was performed to statistically analyze the data by using SPSS 21.0 software. The statistical significance level was set at $p<.05$.
\end{abstract}

Results: NCF values revealed that the HEDM had the highest cyclic fatigue resistance at intracanal temperature $(p<.05)$ and followed by WOG, RPC Blue and OC. The lowest NCF values were determined in the OC group and statistically significant difference was observed between the OC group the other groups $(p<.05)$. No statistically significant difference in the mean length of the fractured fragments in curvature was evident for the instruments ( $p>.05)$.

Conclusion: Within the limitations of the present in-vitro study, HEDM instrument resisted static cyclic fatigue significantly more than RPC Blue, WOG and $\mathrm{OC}$ instruments.
(D)*Koray Yılmaz',
(D) Taha Özyürek ${ }^{2}$,
(D) Gülşah Uslu ${ }^{3}$

ORCID IDs of the authors: K.Y.0000-0001-6096-7385 T.Ö.0000-0003-3299-3361 G.U.0000-0003-3176-1251

\section{Keywords: Endodontics, root canal therapy}

\footnotetext{
1 Department of Endodontics, Faculty of Dentistry, Hatay Mustafa Kemal University, Hatay, Turkey.

2 Department of Endodontics, Faculty of Dentistry, Medeniyet University, İstanbul, Turkey.

3 Department of Endodontics, Faculty of Dentistry, Çanakkale Onkekiz Mart University, Çanakkale, Turkey.
}

How to Cite: Yilmaz K, Özyürek T, Uslu G. Comparison of Cyclic Fatigue Resistance of One Curve, Hyflex Edm, Waveone Gold and Reciproc Blue Nickel-Titanium Rotary Files at Intra-Canal Temperature. Cumhuriyet Dent J 2019;22:1:42-47.

*Corresponding Author

Department of Endodontics, Faculty of Dentistry, Hatay Mustafa Kemal University, Hatay, Turkey

E-mail: koray1903@hotmail.com 


\section{INTRODUCTION}

Nickel-titanium (NiTi) rotary files are the most popular files used in the preparation during the root canal treatment. Beside of advantages such as effective shaping capability, shortening the treatment duration, and helping in maintaining the original form of root canals, NiTi files may also cause negative outcomes such as postoperative pain, periapical pathologies, and failure of treatment in the long-term because of the unexpected instrument fractures during the use of file. ${ }^{1}$

The unexpected failure of NiTi files during the clinical use arises from two different reasons named cyclic or torsional fatigue. ${ }^{2}$ Torsional fatigue failure occurs when the stress, which emerges when the tip of file is stuck at any point in the canal but the shaft keeps rotating, exceeds beyond the elasticity limits of the instrument. ${ }^{3}$ In cyclic fatigue failure, however, the fracture occurs as a result of the accumulation of repetitive tensile and compaction stresses that the file is exposed to in curved canals. The cyclic fatigue was shown to be the main reason for instrument failures during the clinic use. $^{2}$ The kinematics, alloy, and metallurgical properties of instrument are accepted to be among the factors influencing the cyclic fatigue. ${ }^{4,5}$

In order to minimize the failure incidence of NiTi files during the clinical use, the manufacturers apply various heat treatments to the alloys, of which the instruments are made, and they aim to increase the cyclic fatigue resistance of instruments by changing the design properties. $^{6,7}$ One Curve (OC; Micro Mega, Besancon, France) and HyFlex EDM (HEDM; Coltene/Whaledent, Altstatten, Switzerland) are the single file systems working with continuous rotation movement and produced by using different heat treatment procedures. OC is a newgeneration root canal file, which was recently introduced to the market by manufacturer and is produced with $\mathrm{C}$-Wire heat treatment technology. The manufacturer declares that this technology offers $33 \%$ faster root canal preparation in comparison to the reciprocating single-file systems and thus the clinicians would have more time for irrigation. When compared to OneShape
(OS; Micro Mega, Besancon, France), which is the previous-generation single file system of this manufacturer, the cyclic fatigue resistance was reported to be 2.4 times higher.

HEDM, however, works with continuous rotation movement and is made of controlled memory (CM) by using the electronic discharging machining (EDM) technology. This method is based on shaping the file by melting and vaporizing the material through the electrical discharges. EDM technology was reported to give the file a crater-like appearance and an increased resistance to cyclic fatigue. ${ }^{8,9}$

WaveOne Gold (WOG; Dentsply Sirona, Baillagues, Switzerland) and Reciproc Blue (RPC Blue; VDW, Munich, Germany) are the reciprocating single-file systems. WOG is manufactured using gold heat treatment. M-Wire technology is based on the heat treatment before production, whereas the gold heat treatment is performed by heating and then slowly cooling the file after production. The file has a parallelogram cross-section having 2 cutting edges. ${ }^{10,11}$

RPC Blue is manufactured by using a technology (blue heat-treated) altering the molecular structure of file during the production. It was reported that the cyclic fatigue resistance of file increased at the end of this procedure. ${ }^{12}$ RPC Blue has an S-shaped cross section with two cutting edges and a noncutting tip.

In the comprehensive literature review made by the authors of present study, on study examining the cyclic fatigue resistance of OC file was found. For this reason, it is aimed in the present study to compare the cyclic fatigue resistances of single-file systems having different kinematics and heat treatment technologies, which were applied in production process, at the intracanal temperature level. The null hypothesis of present study is that there would be no difference between the cyclic fatigue resistances of NiTi files tested in present study.

\section{MATERIALS AND METHODS}

20 pcs OC (25/.06), 20 pcs HEDM (25/.08), 20 pcs WOG (25/.07), and 20 pcs RPC Blue (25/.08) files were involved in the present study. Before 
using in study, the files were examined by using a stereomicroscope (Olympus BX43; Olympus Co, Tokyo, Japan) in terms of the presence of any defect. Since no defect was found on the files, all of them were involved in the study.

Cyclic fatigue testing was performed in a stainless steel artificial canal manufactured by reproducing the instrument's size and taper. A simulated root canal with a $60^{\circ}$ angle of curvature and 5-mm radius of curvature was constructed for both the instruments tested. The centre of the curvature was $5 \mathrm{~mm}$ from the tip of the instrument and the curved segment of the canal was approximately $5 \mathrm{~mm}$ in length. ${ }^{13}$ Twenty files for each instrument type were operated in distilled water at $35^{\circ} \mathrm{C}^{14}$ Evidence for reduced fatigue resistance of contemporary rotary instruments exposed to body temperaturusing a torquecontrolled endodontic motor (VDW Gold; VDW Munich, Germany). The OC files were used at 450 $\mathrm{rpm}$ and $2.5 \mathrm{gcm}^{-1}$ torque until fracture occurred. The RPC Blue files were used in the "Reciproc ALL" program until fracture occurred. The WOG files were used in the "WaveOne ALL" program until fracture occurred. The HEDM files were used at $500 \mathrm{rpm}$ and $2.5 \mathrm{gcm}^{-1}$ torque until fracture occurred. During experiment, the temperature was measured with an infrared thermometer (GM320, Benetech, CAN $)$ and maintained constant $\left( \pm 1^{\circ} \mathrm{C}\right)$.

The number of cycles to failure (NCF) for each file was calculated using the following formula: $(\mathrm{NFC}=$ revolutions per minute $(\mathrm{rpm}) \times$ time to fracture $(\mathrm{sec}) / 60)$. The fractured fragment length (FL) was determined by a digital micro caliper.

\section{Statistical analysis}

The data were first analyzed using the ShapiroWilk test to verify the assumption of normality. The Kruskal-Wallis test was performed for statistically analyze the data by using SPSS 21.0 (IBM-SPSS Inc, Chicago, IL) software. The statistical significance level was set at $\mathrm{p}<.05$.

\section{RESULTS}

Mean NCF and FL values and standard deviations of the files are presented (Table 1).
Table 1. The Means and Standard Deviations of the Number of Cycles to Failure (NCF) and Fracture Length (FL) of Instruments in Distilled Water at $35^{\circ} \mathrm{C}$.

\begin{tabular}{|c|c|c|c|c|}
\hline \multirow[b]{2}{*}{ Group } & \multicolumn{2}{|c|}{$\mathrm{NCF}$} & \multicolumn{2}{|c|}{ FL } \\
\hline & Mean & $\begin{array}{l}\text { Standard } \\
\text { Deviation }\end{array}$ & Mean & $\begin{array}{l}\text { Standard } \\
\text { Deviation }\end{array}$ \\
\hline $\begin{array}{c}\text { WaveOne } \\
\text { GOLD }\end{array}$ & $1355.3^{a}$ & 216.8 & 5.4 & 0.3 \\
\hline $\begin{array}{l}\text { Reciproc } \\
\text { Blue }\end{array}$ & $1245.5^{\mathrm{a}}$ & 195.2 & 5.5 & 0.5 \\
\hline $\begin{array}{c}\text { HyFlex } \\
\text { EDM }\end{array}$ & $1647.3^{b}$ & 239.6 & 5.3 & 0.2 \\
\hline One Curve & $864.2^{\mathrm{c}}$ & 129.6 & 5.7 & 0.8 \\
\hline$p$ - value & & $<.05$ & & $>.05$ \\
\hline
\end{tabular}

$\mathrm{NCF}$ values revealed that the HEDM had the highest cyclic fatigue resistance at intracanal temperature $(\mathrm{p}=0.001)$ and followed by WOG, RPC Blue and OC. There were no significant differences between the WOG and RPC Blue (p>.05). The lowest NCF values were determined in the OC group and statistically significant difference was observed between the OC group the other groups $(\mathrm{p}=0.912$ ).

The mean length of the fractured fragment was also recorded to evaluate the correct positioning of the tested instrument inside the canal curvature and whether similar stresses were being induced. No statistically significant difference in the mean length of the fractured fragments in curvature was evident for the instruments ( $p>05)$.

\section{DISCUSSION}

The complication that is most frequently observed by the clinicians during the root canal treatments is the NiTi instrument failures. ${ }^{15}$ The previous studies showed that the main reason for these instrument failures is the cyclic fatigue. ${ }^{16,17}$ The reciprocal movement decreases the torsional stress, which the instruments are exposed to inside the root canal, and the consequent torsional fatigue $^{18}$, and it also positively contributes to the cyclic fatigue resistance of instruments. ${ }^{19}$ The canal instruments, which generally work by reciprocating, are produced in single-file form, and they are recommended for using in 2 or 3 canals depending on the anatomic complexity of teeth, in which they are used. For this reason, the cyclic fatigue test is much more important to the 
reciprocating files. ${ }^{13}$ The manufacturer companies generally apply different heat treatments to the files in order to improve the cyclic fatigue resistance of files, and they aim to minimize the incidence of instrument failures. In the present study, it was aimed to compare the cyclic fatigue resistances of 4 current rotary single file systems named HEDM (CM-Wire), WOG (Gold-Wire), RPC Blue (Blue-Heat Treated), and OC (C-Wire) that are subject to different heat treatments and work with different kinematics.

The cyclic fatigue tests have not been exactly standardized yet and there is no test procedure, on which all the researchers could arrived at a consensus. ${ }^{20}$ Plotino et al. ${ }^{21}$ recommended the use of stainless steel canals, which are specific to the tested files (size and taper) in order for files to follow the same trajectory in the static cyclic test setups. For this reason, the stainless steel artificial canals, which were prepared specific to the sizes and tapers of files tested in the present study, were used.

In their study, de Hemptinne et al. ${ }^{22}$ reported the intra-canal temperature to be $35^{\circ} \mathrm{C}$ and it was reported in previous studies that the NiTi files might be affected from the intra-canal temperature. For this reason, the cyclic fatigue test of heat-treated NiTi canal files was performed at $35 \pm 1{ }^{\circ} \mathrm{C}$ in order to mimic the clinical conditions.

According to the results obtained in present study, the cyclic fatigue resistance of HEDM files was found to be statistically significantly higher than WOG, RPC Blue, and OC files ( $\mathrm{p}<.05)$. For this reason, the null hypothesis of present study was rejected. Pedulla et al. ${ }^{20}$ (2016) compared the cyclic fatigue resistances of HEDM, Reciproc (VDW), and WaveOne (Dentsply Sirona), and they reported the cyclic fatigue resistance of HEDM file to be higher. They asserted that this is because HEDM file is made of CM alloy by using EDM technology. Özyürek et al. ${ }^{12}$ tested the cyclic fatigue resistance of HEDM, WOG, RPC Blue, and 2shape (TS; Micro-Mega, Besancon, France) files in the artificial canals having $45^{\circ}$ and $90^{\circ}$ slope, and they compared the time-to-fracture (TTF) values obtained in that study. The researchers reported that, when compared to the other files, RPC Blue had higher cyclic fatigue resistance in both of canals having different slope levels. Pedulla et al. ${ }^{8}$ performed the cyclic fatigue tests at the room temperature, whereas the tests were conducted at the intra-canal temperature in the present study. Similarly, Özyürek et al. ${ }^{12}$ compared the TTF values, whereas the NCF values were compared in the new study. The authors of present study assert that the results obtained here are different from the literature because of the differences between the methodologies.

According to the results of present study, no statistically significant difference was found between the cyclic fatigue values of RPC Blue and WOG files ( $p>.05)$. In a study on comparing the cyclic fatigue resistance of RPC Blue, RPC, and WOG files, RPC Blues showed better cyclic fatigue values than the others did. $^{3}$ According to the results obtained here, on the contrary with the results of other study, the difference between the cyclic fatigue resistances of RPC Blue and WOG files might be because of the tests performed at the room temperature and the cyclic fatigue resistance and the comparison between cyclic fatigue values by taking the TTF values into consideration.

Since OC file is a newly introduced file, there is no study in the literature, which can be used in directly comparing with the present results. The manufacturer alleges that $\mathrm{OC}$ file has 2.4 times higher cyclic fatigue resistance when compared to OneShape (OS; Micro Mega,) file. They assert that this is because of the C-Wire heat treatment used in the production, which is different from OS file ${ }^{7}$. Gündoğar \& Özyürek ${ }^{7}$ compared the cyclic fatigue resistances of OS, HEDM, RCP Blue, and WOG files. They reported that HEDM file has the maximum cyclic fatigue resistance, whereas the minimum value was observed in OS files. It is thought that, despite the heat treatment applied, the OC file showed lower cyclic fatigue resistance than RPC Blue and WOG because of the different kinematics of the files.

\section{CONCLUSIONS}

Within the limitations of the present in-vitro study, HEDM instrument resisted static cyclic 
fatigue significantly more than RPC Blue, WOG and OC instruments. The novel NiTi rotary instrument OC showed significantly lowest cyclic fatigue resistance compared to the other systems.

\section{ACKNOWLEDGEMENT}

Author Dr. Koray YILMAZ declares that he has no conflict of interest. Author Dr. Taha ÖZYÜREK declares that he has no conflict of interest. Author Dr.Gülşah USLU declares that she has no conflict of interest.

\section{CONFLICTS OF INTEREST}

None

\section{İçi Sıcaklıkta Döngüsel Yorgunluğa Karşı Dirençlerinin Karşılaştırılması}

\section{$\ddot{O} Z$}

Amaç: One Curve (OC), Hyflex EDM (HEDM), WaveOne Gold (WOG) ve Reciproc Blue (RPC Blue) NiTi döner kanal aletlerinin kanal içi sicaklıkta (35) döngüsel yorgunluğa karşı gösterdikleri dirençlerin karşılaş̧ırılmasıdır. Gereç ve Yöntemler: Yirmi OC (25/,06), 20 HEDM (25/,08), 20 WOG (25/,07) ve 20 RPC Blue $(25 /, 08)$ kanal aleti kanal içi sicaklıkta (35\%) döngüsel yorgunluk direnci testine dahil edildi. Tüm kanal aletleri, $60^{\circ}$ kurvatur açısı ve $5 \mathrm{~mm}$ kurvatur yarıçapına sahip paslanmaz çelik yapay kanallarda kırılıncaya kadar döndürüldü. Kırllıncaya kadar geçen süreler djital kronometre ile ölçülüp saniye cinsinden kaydedildi ve kırllıncaya kadarki tur sayıları (KKTS) hesaplandl. SPSS 21.0 yazılımında Kruskal-Wallis testi ile istatistiksel analiz yapıldi. İstatistiksel anlamlılık değeri $p<, 05$ olarak tespit edildi. Bulgular: KKTS değerlerine bakıldığında HEDM kanal içi sıcaklığında en yüksek döngüsel yorgunluk direnci değerlerini göstermiştir $(p<, 05)$ ve onu sirasıly WOG, RPC Blue ve OC takip etmektedir. Diğer gruplar ile karşılaşstırıldı̆̆ında istatistiksel olarak anlamlı derecede en düşük döngüsel yorgunluk direncini OC göstermiştir $(p<05)$. Aletlerin kırı uzunlukları açısından istatistiksel olarak aralarında anlamlı bir farklılık yoktur. (p>,05). Sonuç: Çalışmamızın limitasyonları dahilinde döngüsel yorgunluğa karşı en yüksek direnci RPC Blue, WOG ve OC' ile klyaslandı̆̆ında HEDM kanal ĕgesi göstermiştir.

Anahtar Kelimeler: Endodonti, kök kanal tedavisi.

\section{REFERENCES}

1. Ankrum MT, Hartwell GR, Truitt JE. K3 Endo, ProTaper, and ProFile systems: breakage and distortion in severely curved roots of molars. J Endod 2004; 30 : 234-237.

2. Shen Y, Cheung GSP, Bian Z, Peng B. Comparison of defects in ProFile and ProTaper systems after clinical use. J Endod 2006; 32:61-65.

3. Martin B, Zelada G, Varela P, et al. Factors influencing the fracture of nickel-titanium rotary instruments. Int Endod J 2003; 36:262-266.

4. Kitchens GG, Liewehr FR, Moon PC. The effect of operational speed on the fracture of nickel-titanium rotary instruments. J Endod 2007; 33:52-54.

5. Bui TB, Mitchell JC, Baumgartner JC. Effect of electropolishing ProFile nickel-titanium rotary instruments on cyclic fatigue resistance, torsional resistance, and cutting efficiency. J Endod 2008; 34:190-193.

6. Peters OA, Gluskin AK, Weiss RA, Han JT. An in vitro assessment of the physical properties of novel Hyflex nickel-titanium rotary instruments. Int Endod J 2012; 45:1027-1034.

7. Gündoğar M, Özyürek. Cyclic Fatigue Resistance of One Shape, HyFlex EDM, Wave One Gold, and Reciproc Blue Nickel-titanium Instruments. J Endod 2017; 43: 1192-1196.

8. Pedulla E, Lo Savio F, Boninelli S, Plotino G, Grande NM, La Rosa G, Rapisarda E. Torsional and Cyclic Fatigue Resistance of a New Nickel-Titanium Instrument Manufactured by Electrical Discharge Machining. J Endod 2016; 42:156-159.

9. Yılmaz K, Uslu G, Özyürek T. Effect of multiple autoclave cycles on the surface roughness of HyFlex $\mathrm{CM}$ and HyFlex EDM files: an atomic force microscopy study. Clin Oral Investig 2018; 9:29772980.

10. WaveOne Gold brochure. Available at: https://www.dentsply.com/content/dam/dentsply/pim/ manufacturer/Endodontics/Obturation/Gutta_Percha_P oints/WaveOne_Gold_Gutta_Percha_Points/W1G_Bro chure_EN.pdf. Accessed July 10, 2017.

11. Özyürek T. Cyclic Fatigue Resistance of Reciproc, WaveOne, and WaveOne Gold Nickel-Titanium Instruments. J Endod 2016; 42:1536-1539.

12. Özyürek T, Uslu G, Yılmaz K, Gündoğar M. Effect of Glide Path Creating on Cyclic Fatigue Resistance of Reciproc and Reciproc Blue Nickel-titanium Files: A Laboratory Study. J Endod 2018; 44:1033-1037.

13. Plotino G, Grande NM, Testarelli L, Gambarini G. Cyclic fatigue of Reciproc and WaveOne reciprocating instruments. Int Endod J 2012; 45: 614-618.

14. de Vasconcelos RA, Murphy S, Carvalho CA, Govindjee RG, Govindjee S, Peters OA. Evidence for Reduced Fatigue Resistance of Contemporary Rotary Instruments Exposed to Body Temperature. J Endod 2016; 42: 782-787.

15. Shahabinejad H, Ghassemi A, Pishbin L, Shahravan A. Success of ultrasonic technique in removing fractured rotary nickel-titanium endodontic instruments from root canals and its effect on the required force for root fracture. J Endod 2013; 39:824-828. 
16. Cheung G, Peng B, Bian Z, Shen Y, Darvell BW. Defects in ProTaper S1 instruments after clinical use: fractographic examination. Int Endod J 2005; 38:802809.

17. Inan U, Gonulol N. Deformation and fracture of Mtwo rotary nickel-titanium instruments after clinical use. J Endod 2009; 35:1396-1399.

18. Castello-Escriva R, Alegre-Domingo T, FausMatoses V, et al. In vitro comparison of cyclic fatigue resistance of ProTaper, WaveOne and Twisted Files. J Endod 2012; 38: 1521-1524.

19. Yared G. Canal preparation using only one Ni-Ti rotary instrument: preliminary observations. Int Endod J 2008; 41:339-344.

20. Plotino G, Grande NM, Cordaro M, Testarelli L, Gambarini G. A review of cylic fatigue testing of nickel-titanium rotary instrument. J Endod 2009; 35:1469-1476.

21. Yılmaz K, Uslu G, Gündoğar $M$, Özyürek $T$, Grande NM, Plotino G. Cyclic fatigue resistances of several nickel-titanium glide path rotary and reciprocating instruments at body temperature. Int Endod J 2018; 51: 924-930.

22. de Hemptinne F, Slaus G, Vandendael M, Jacquet W, De Moor RJ, Bottenberg P. In Vivo Intracanal Temperature Evolution during Endodontic Treatment after the Injection of Room Temperature or Preheated Sodium Hypochlorite. J Endod 2015; 41: 1112-1115. 23. Özyürek T, Gündoğar M, Uslu G, Y1lmaz K, Staffoli S,Gramde NM, Plotino G, Polimeni A Cyclic fatigue resistances of Hyflex EDM, WaveOne gold, Reciproc blue and 2shape NiTi rotary files in different artificial canals. Odontology 2018; 4:408-413. 